KOLTAI Tamás - ROMHÁNYI Gábor - TATAY Viola

\section{OPTIMALIZÁLÁS BIZONYTALAN \\ PARAMÉTEREKKEL A TERMELÉS- ÉS SZOLGÁLTATÁSMENEDZSMENTBEN}

A termelố- és szolgáltatórendszerek múködésének optimalizálása a termelésmenedzserek egyik gyakori problémája. Többek között az optimális termékszerkezet meghatározása, az optimális rendelési politika alkalmazása, a legkedvezóbb szálítási/logisztikai folyamatok kialakítása, a hulladékkezelés és anyagforgalom optimalizálása ismétlódó jelleggel felmerüló menedzsmentfeladatok. Az optimalizáló modellek alkalmazóinak a legtöbb nehézséget rendszerint az okozza, hogy a számítások elvégzéséhez szükséges adatok (paraméterek) értéke bizonytalan, az adatok rendszerint kiszámíthatatlanul és nem feltétlenül statisztikailag véletlenszerúen változnak. E cikk néhány egyszerú példa segítségével mutatja be a paraméterek bizonytalanságából eredô problémák kezelésének lehetséges módszereit és azok menedzsmentvonatkozásait.

Kulcsszavak: optimalizálás, termelésmenedzsment, szolgáltatásmenedzsment, érzékenységvizsgálat

A hétköznapi nyelvben gyakran használjuk az „op- egy leginkább jó. Ezt a megtalált optimális vagy nem timalizálás” kifejezést. Keressük például az optimá- optimális megoldást nevezik (helytelenül) legoptimá-

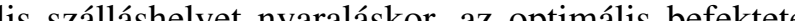
megtakarított pénzünknek. Néha optimálisnak tarjuk a vízhómérsékletet a Balatonnál vagy az idójárási viszonyokat egy kiránduláshoz. E szóhasználat arra uta hogy ami optimális, az a lehetô legjobb.

Optimumkeresés

a termelés- és szolgáltatásmenedzsmentben

A hétköznapi életben a kifejezést nem használjuk pontosan. Nem tudjuk ugyanis kiválasztani a világ öszszes nyaralóhelyéból a számos szempont (ár, távolsás. idojárási viszonyok, programlehetôségek stb.) szerin legjobbat. Ilyenkor valójában nem optimális, hanem kielégitô megoldást keresünk. Az ilyen megoldást keres dontési mechanizmus figyelembe veszi az optimumk resés korlátozott lehetôségeit, a korlátozott racionalitást (Simon, 1982). A korlátozott racionalitás tudattala alkalmazásának köszönhető az elméletileg önmagának ellentmondó „legoptimálisabb” kifejezés szinte mindennapos használata. Ha ugyanis valami optimális, akkor az a legjobb, tehát nincs annál jobb. Ha viszont ez a legjobb nem található meg, akkor a sok jó között van sabbnak.

matematikában az optimum egy célfüggvény szélsőértékét (maximumát vagy minimumát) jelenti. Az optimalizálás ennek a szélsőértékének a meghatározása A matematikai értelemben vett optimalizálás alkalmazása az üzleti életben valamilyen gazdasági vonatkozású célfüggvény adott feltételek melletti maximumának (például fedezetmaximalizálás) vagy minimumának (például költségminimalizálás) a meghatározása. Az ilyenkor alkalmazott technikák az operációkutatás tárgykörébe tartoznak. Az operációkutatás kialakulása termelésben végbement specializáció egyik következménye. A középkori ip arosokńl és a késóbbi ma-

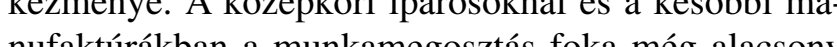
volt egy vagy néna

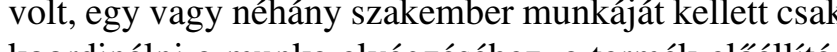

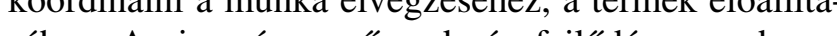
sâhoz. Az ipar és mezógazdaság fejlódése azonban a munkamegosztás növekedéséhez, és ezzel együtt egyre nagyobb mértékú koordináció szúkségességéhez vezetett. A specializáció növekedése miatt egyre nehezebb feladatot jelentett a rendelkezésre álló erôforrások külônbözó felhasználási lehetôségek közötti szétosztása. Ezért előtérbe került az erőforráskorlátok szem- pontjából optimális múködés kialakítása. A múködés (operation) tudományos vizsgálatával (research) fogialakult tudományterület, az operációkutatás (operations research) feladata tehát nem más, mint a rendszerek (szervezetek) múködés nek elemzése és optimális múködésük meghatározása. A korlátozott racionalitás miatt a legtöbb optimalizáló modell csak meghatározott korlátok melletti optimumot jelent. Ez azonban menedzsmentszempontbo elfogadható. A termelés- és szolgáltatásmenedzsmentben sok olyan részprobléma található, amelyet egy opben sok olyan részproblés szalán há, a melyet egy op-

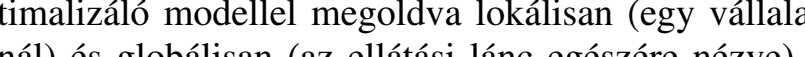
nál) és globálisan (az elláasi lánc egészére nézve) a jelenleginél jobb mukködést kapunk. Egy raktár m kơdésének kölsege peldunl jelentósen csokkenthetó készlettartási költségek minimalizálásával; az árbevéte jelentôsen nôvelhetó az optimális termelési terv meghatározásával; a vevói elégedettség javítható a vevố várakozási idejének minimalizálásával. Az ezekhez hasonló problémák modellezése és megoldása az oper ciókutatás jól kialakult módszereivel elvégezhetố.

A komplex gyakorlati problémák megoldásához ma már olyan eszközök állnak rendelkezésre, amelyek segítik a modellalkotást, lehetôvé teszik nagyméretú modellek gyors megoldását, és támogatják a döntés-elökészítés folyamatát. Kisebb, néhány száz változóból es korlátból álló modellek egyszeń táblóz vátozóból és korlấb ă szerek segitségevel is megol hal es nagyobb feladatok a matenatikai modellezési nyevekben egyszerúen program verekkel kezelhetók (peldául Lingo, XA). Az utóbb idóben elterjedóben vannak olyan optimalizáló kere szoftverek is, amelyek a modellfejlesztést, a számítást és az eredmények illusztrálását a menedzserek számár könnyen érthető grafikai felületekkel támogatják (például AIMMS). Az optimalizálási döntések elméletét és gyakorlatát egyesítő modellezésalapú szakkönyve pedig az eredmények értelmezésében segítenek (lás például Koltai, 2006; Kovács, 2001; Ragsdale, 2007; Vörös, 1991)

Az optimalizálás gyakorlati alkalmazását a mindennapi döntéshozatalban tehát az elmélet és a gyakorlati eszközök egyaránt jól támogatják. E módszerek alkalmazásának ugyanakkor egyik legnagyobb problémáj a rendelkezésre álló adatok pontatlansága.

A pontatlan adatok hatásának vizsgálata

Az alkalmazott optimalizáló modell matematikai tulajdonságaitól, valamint a bizonytalanság okától és jellegétôl függ az, hogy egy paraméter pontatlanságána következménye hogyan vizsgálható. A továbbiakban a paraméterek változását és a változás hatásának felmérését segítő módszereket tekintjük át, és illusztráljuk néhány egyszerú példával.

A paraméterérzékenység analitikus vizsgálata

Az optimalizálási modelleknél gyakran explici módon meghatározható valamely paraméter változásának a célfüggvényre kifejtett hatása. A paraméter és a célfüggvényérték kapcsolatát leíró képlet vagy algoritmus segítségével egyrészt számszerú eredményt, másrészt a menedzsment számára jól alátámasztott általános öszzfïggéseket kapunk. Ennk szemléltetéśc tekintsïnk egy egyszerí termelésterveźsi péld́

A termeléstervezési problémákat gyakran oldják neg lineáris programozással (LP). Egy lineáris programozási probléma általánosan a következőképpen írható fel:

$$
\begin{aligned}
\operatorname{Max} \mathrm{F}=\underline{\mathbf{c}}^{\mathrm{T}} \underline{\mathbf{x}} \\
\mathbf{A} \underline{\mathbf{x}} \leq \underline{\mathbf{b}} \\
\underline{\mathbf{x}} \geq 0
\end{aligned}
$$

Az általánosan felírt feladatban $\underline{\mathbf{x}}$ vektor tartalmazza a döntési változókat (például az idôszakonként gyártandó mennyiséget), $\mathbf{c}$ vektor jelenti a célfüggvény-együtthatókat (például fajlagos költségeket, fajlagos árakat vagy fajlagos fedezeteket). A b vektor a korlátón feltételek jobb oldali partécterit fogla mán (pátula igen igenyeket, rendelkezésre alló munkaórakal). Az A mátrix pedig a dôntési valtozók és a korlátok kapcsolatát kifejezó erốforrás-felhasználási egyuttthatókat tartalmazó együtthatómátrix. A feladat a célfüggvényt maximalizáló, de a korlátokat teljesítő optimális megoldás megtalálása. Egy termeléstervezési problémánál például a fedezetet maximalizáló, de a piaci, gyártási és technológiai korlátokat betartó termelési terv meghatározása lehet a feladat. A legtöbb kereskedelmi forgalomban kapható LP szoftver az optimális megoldás mellé automatikusan szolgáltatja a célfügovényegyütthatók és a jobb oldali paraméterek érzékenységvizśt és a jón old (Koltai - Terlaky, 2000; Koltai - Tatay, 2008).

Az 1. táblázat egy termeléstervezési probléma jobb oldali paramétereinek érzékenységvizsgálati eredményeit szemlélteti (Koltai, 2006). A feladat: meghatározni a legalacsonyabb költségú termelési tervet hat hónapon keresztül havi bontásban, figyelembe véve a vevói igényeket, az alkalmazottak létszámának változását, valamint a létszám és a termelési mennyiség közötti kapcsolatot leíró termelékenységi összefüggéseket. A hat hónapon keresztül jelentkezô piaci igényeket leró feltételek a következók: 
$P_{t}-I_{t}+I_{t-1}=D_{t} \quad t=1, \mathrm{~K}, 6$

(2) licit módon kifejezhetố (Koltai, 2006). Hálótervezésné a végrehajtási idốk változásának hatása a tartalékidók elemzésével analitikusan vizsgálható (Waters, 1996) A sorozatindítási költséget is tartalmazó nemlineáris termeléstervezési modelleknél a költségérzékenység a dinamikus programozás eszközeivel számolható (Hillier - Liberman, 1995). Ütemezési problémáknál az eredmény érzékenysége a készlettartási ráta változására ugyancsak meghatározható (Koltai, 2007).

A termeléstervezési probléma jobboldali paramétereine

zékenységvizsgálata

\begin{tabular}{|c|c|c|c|c|c|}
\hline Név & $\begin{array}{c}\text { Végérték } \\
(\mathbf{d b})\end{array}$ & $\begin{array}{c}\text { Árnyékár } \\
(\mathbf{e ~ F t})\end{array}$ & $\begin{array}{c}\text { Feltétel } \\
\text { jobb oldala }\end{array}$ & $\begin{array}{c}\text { Megengedhető } \\
\text { növekedés }\end{array}$ & $\begin{array}{c}\text { Megengedhetó } \\
\text { csökkenés }\end{array}$ \\
\hline Igény 1 & 1280 & $-24,178$ & 1280 & 25,882 & 3520,000 \\
\hline Igény 2 & 640 & $-16,178$ & 640 & 348,421 & 88,000 \\
\hline Igény 3 & 900 & $-8,178$ & 900 & 348,421 & 88,000 \\
\hline Igény 4 & 1200 & $-0,178$ & 1200 & 348,421 & 88,000 \\
\hline Igény 5 & 2000 & 5,979 & 2000 & 933,333 & 2520,000 \\
\hline Igény 6 & 1400 & 13,979 & 1400 & $\infty$ & 636,364 \\
\hline
\end{tabular}

Az igény feltételezett értéke januárban 1280 darab (Feltétel jobb oldala), amely az eredményül kapott termelési terv alapján ki is elégíthetô (Végérték). Ha azonban az igény valamilyen oknál fogva egységnyivel (egy tervet kapunk, amely az eredeti tervnél 24178 forinttal tervet kapunk, amely az eredeti ternél 24178 forintt (Arnyêkar) alacsonyabb kölségú. Érdemes tehát ösztönözni - akár árkedvezménnyel is - a vevóket, hogy januárban többet rendeljenek. Az igény változása matti 24187 forintos fajlagos költségcsökkenés azonban csak 25882 darabnál kisebb többletrendelésre érvényes (Megengedett növekedés). Ennél nagyobb változásokra már más adat érvényes. Az igény egységnyi csökkenésének hatása fordított előjelứ költségváltozást, tehă 24187 forint költségnövekedést okozna.

A táblázatból az is látható, hogy az elsố négy hónapban az igény növekedése (a meglévő felesleges kapacitások jobb kihasználása miatt) a termelési terv költségének csölkkenéśnez vezet. Ugyanakkor az utolsó két hón çan a kapactások szúkös rendelkeźs allása miat az igeny növekedése magas re kolsegu optimális eruelesi terval eléthetó csak ki. Ekkor optimális termelési tervvel elégíthetố csak ki. Ekkor további igények megjelenése esetén felár számítás indokolt (májusban például minimum 5979 forint darabonként).

$\mathrm{Az}$ ismertetett termeléstervezési példán túl sok más esetben is végezhetố analitikus érzékenységvizsgálat. A készletezési döntéseknél például az optimális rendelési tételnagyság érzékenysége a fő paraméterekre expA paraméterérzékenység numerikus vizsgálata
Amikor analitikus összefüggések segítségével nem tudjuk vizsgálni egy bizonytalan paraméter hatását, akkor numerikusan, a paraméter értékét këzvetlenül megécét ét két kismértékben megvaltoztatva - a paraméter érkét perturbálva - újra megoldjuk a vizsgálni kívánt problemmát, majd meghatározzuk a valitozást. Gyakran a perturbált paraméterértékkel nem kell megoldani a feladatot, mert lehetséges a végeredmény változásának vizsgálata speciális módszerekkel, kizárólag a változás lésütemezési példát

A numerikus érzékenységvizsgálat végrehajtásának egyik lehetséges módja a szabályozáselméletben kifejlesztett perturbációelemzés alkalmazása (Ho - Cao, 991). Ennek lényege, hogy a diszkrét időpontokban történő́ állopotváltoźs alapján múködó iondszontokban az esemén

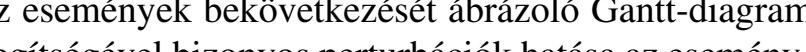
segítségével bizonyos perturbációk hatása az esemén A

Az 1. ábra egy acélipari üzem öntési folyamatát követő kemencében végrehajtott másodlagos metallurgiai kezelést követôen a folyékony acél az ábrán jelzett két öntôfej valamelyikéhez kerül. Ha a folyékony acél túl korán ér az öntốfejhez, akkor megszilárdul, és öntésre alkalmatlanná válik. Ha viszont túl késôn kerül az öntőfejhez, akkor a folyamatos öntés megszakad, és követésével. Lássunk erre a következókben egy termeszemlélteti. A konverterben felolvasztott, majd az azt a készülő öntvény károsodik. A folyamat tevékenységeinek végrehajtási sorrendjét egy optimális ütemezést meghatározó modell szolgáltatja. A metallurgiai kezelés ideje azonban változhat. $\mathrm{E}$ változás hatásait fontos elôre jelezni és a folyamatot szükség esetén idóben a kell ütemezni. Perturbációelemzéssel vizsgáltuk a konverterben eltöltött idő változásának hatását az öntőfejek elốtti várakozás idejére, és jeleztük, amikor a változás olyan mértékú, hogy a folyamat átütemezése szükséges (Koltai et al., 1993).

\section{A folyamatos öntôsor egyszerúsített} folyamatábrája

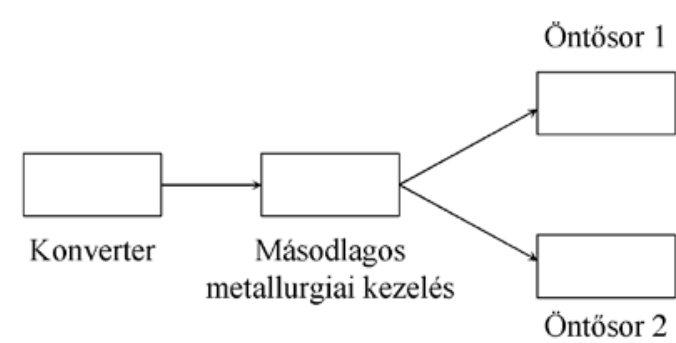

A perturbációelemzés azért tekinthetố numeriku érzékenységvizsgálatnak, mert ugyan nem oldjuk meg újra a teljes feladatot egy paraméter megváltozott értékére, de minden változás esetében végre kell hajtani a számítást. Nincs tehát általános összefüggésünk a változás és a hatás kapcsolatának közvetlen és általános tozás és a hatás kapcsolatin

A perturbációelemzés mellett sok más technika is alkalmazható numerikus érzékenységvizsgálatnál. Kapacitások változása, meghibásodások elôfordulása, valamint a kapacitást befolyásoló karbantartási foly matok végrehajtási ideje például jól vizsgálható Monte-Carlo, valamint diszkrét szimulációval (lásd példáu Kövesi, 1991; Kovács, 2008). Az ipari folyamatokba áramló anyag mennyiségének változása egyes rendszerparaméterek változása miatt pedig jól követhetố a

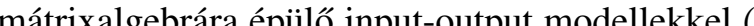
- Romhányi, 1983).

\section{Fuzzy paraméterek használata}

Az ismertetett módszerek mindegyikénél feltételeztünk valamilyen konkrét paraméterértéket. $\mathrm{E}$ feltételezett értékkel elvégeztük az optimalizálást, maj megvizsgáltuk a paraméter esetleges változásának következményeit. Gyakran előfordul azonban, hogy egy paraméternél nem tudunk megnyugtató induló értéket választani. Ilyenkor használható a menedzsmentterületen viszonylag újszerünek számító fuzzy halmazok elmélete (Bellman - Zadeh, 1970; Zimmermann, 1988).
Egy fuzzy halmaz a következóképpen definiálható:

Legyen az $X=\{x\}$ az objektumok (pontok) halmaza, ahol az egyes objektumokat $x$ jelöli. Egy fuzzy halmaz (A) a következó rendezett párok halmaza:

$$
A=\left\{\left(\underline{\mathbf{x}}, \mu_{A}(\underline{\mathbf{x}})\right)\right\}, \quad \underline{\mathbf{x}} \in X
$$

ahol $\mu_{A}(x)$ az $x$ objektum tagsági függvénye az $A$ halmazban, és $\mu_{1}: X \rightarrow M$ olyan függvény, amely az $x$ pontok halmazából leképzi az $M$ tagsági teret. Ha a tagsági függvény csak a 0 és 1 értékeket tartalmazza, akkor $A$ egy hagyományos Boole-algebrai halmaz, és a tagság függvény egy nem-fuzzy halmaz jellemzójét defagáálja Tételezzük fel, hogy egy megmunkáló berendezés kaTételezzk fel, ha pacitását kell for gacitás ismert és pontosan 1400 darabo, akkor egy hagyomanyos, nemfuzzy halmazzal ítuk le a kapacitást. A tagsági függvény ugyanis csak 0 és 1 ertékeket tartalmaz. Egy kapacitásérték vagy tagja a kapacitás lehetséges êrtékeit tartalmazó halmaznak (tehát 1400), vagy nem (például 1500). Ha viszont a kapacitás lehetséges értékét 1000 és 1500 közé feltételezzük, és a tényleges értéket valamilyen szubjektív megítélést kifejező normált tagsági függvénnyel írjuk le, akkor a tagsági tér 0 és 1 között bármilyen értéket tartalmazhat. A fuzzy halmaz eleme ekkor az 1000 és 1500 közé eső kapacitásértékek bármelyike lehet, de az egyes értékek szubjektív megítélése eltérō.

A 2. ábra lineáris tagsági függvényt feltételezve szemlélteti a kapacitásértékek fuzzy halmazát. Az ábra az (1) LP feladat egy $j$ korlátiának fuzzy értelmezését mutatja. Az ábrán $\Delta b$ jelöli a fuzzy tartományt, amelynek alsó értéke $b$. Példánk szerint: tehát $b=1000$ és $\Delta b=500$, így a tartomány felső határa 1500 . A csökkenố lineáris tagsági függvény azt fejezi ki, hogy kisebb kapacitásérték elófordulásának szubjektív megítélése aranyosan magasabb, mint nagyobb kapacitásérték elốfordulásáé. 1500 felett a kapacitásérték lehetőségét zéróval jellemezzük, míg 1000 alatt a kapacitásértéket a biztos előfordulást kifejező 1 érték jellemzi.

Fuzzy paraméter

lineáris tagsági függvénnyel

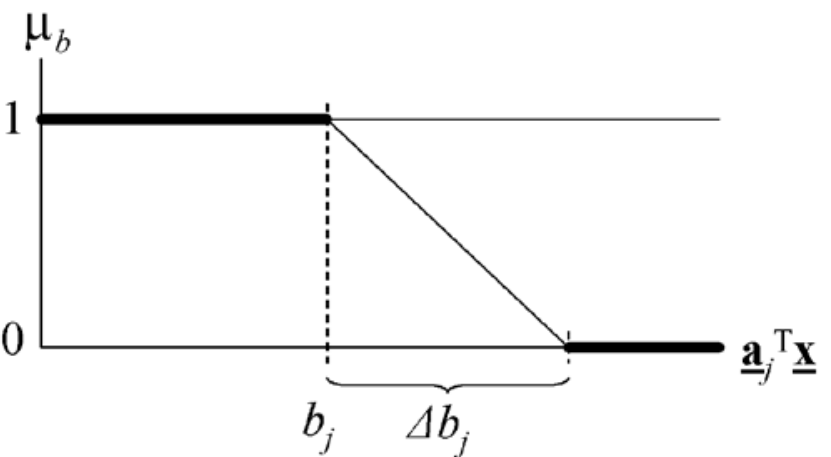


Hangsúlyozni kell, hogy a kapacitás a fuzzy értelmezésben nem valószínúségi változó. Nem azt feltémilyen valószínúséggel előfordul. A kapacitás a jelölt tartományban bármilyen értéket biztosan felvehet, de ezekhez az értékekhez valamilyen szubjektív megítélést rendelünk.

A lineáris tagsági függvény használatakor bármely lineáris termeléstervezési modell a jobb oldali paraméterek fuzzy értelmezésekor is lineáris marad, és így könnyen megoldható (Koltai - Tatay, 2009). Nemliné ris tagsági függvény segítségével a számítás ugyan bonyolultabb, de ré́lisab menedzsment-megfontolsok érvényesíthetók a bizonytalan paraméterekkel kapcsolatban.

A fuzzy halmazok használata a múszaki életben elố forduló bizonytalanságoknál már viszonylag régóta e aránylag kevés, de ugyanakkor meggyőző erejú péld található a szakirodalomban (például Shih, 1999). Termeléstervezési problémáknál a fuzzy kapacitásparaméterek és fuzzy igényparaméterek használata különösen sokat segíthet a paraméterek bizonytalanságából eredô problémák kezelésében (Koltai - Tatay, 2009). Nem kell ugyanis elôre egy meghatározott értéket feltételezni, majd késóbb vizsgálni a használt induló érték változásának hatácát. Elegendő egy paraméter lehetséges zásának háácut. egy szubjektív tartalmú tagsági függvényt rendelni.

\section{Összefoglalás}

E cikkben összefoglaltuk azokat a technikákat, amelyek segítségével bizonytalan adatok esetén is lehetsé döntések támogatásához.

Gyakran analitikus technikákkal a bizonytalanságból eredô pontatlanság következményei elôre felmérhetốk és a pontatlanság csökkentésére szánt ráfordítások valamint a pontatlanság kedvezőtlen következményei összevethetók A cikkben bemutatott termeléstervezési osszéldához hasón technḱ́k többek között a tervezés

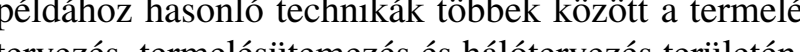
tervezés, ternér. megtalálhatók. technikák is alkalmazhatók. A számítástechnika gyor fejlődésének köszönhetốen ma már a paramétere változásának követése és következményeinek meghatározása bonyolult rendszerek esetén is lehetséges. A perturbációelemzés segítségével összetett ütemezés problémák paraméterváltozásra történő érzékenysége még a döntéshozatal számára rendelkezésre álló, gyaktelezzük, hogy a kapacitás 1000 és 1500 között valafogadott. Menedzsmentproblémák modellezésére még ges optimalizálo módszerek használata menedzsment-

Analitikus eszközök hiányában gyakran numerikus

ran igen rövid idố alatt is meghatározható. A cikkben zt egy öntödei folyamat segítségével szemléltettük. Végezetül, ha csak hozzávetốleges információnk van egy paraméter értékének lehetséges tartományáról, akkor a fuzzy paraméterek alkalmazása segíthet az optimalizálásban.

Hangsúlyozni kell, hogyha egy adat bizonytalan, akkor a bizonytalanság miatti információveszteség nem pótolható, legfeljebb annak következménye enyhíthetố a paraméterváltozás hatásának minél pontosabb feltérképezésével. Az elmondottak alapján tehát megállapíthatjuk, hogy az adatok pontatlanśga ́́s bizonytalańá nem lot talansaga nen lehet akadálya az optimalizáló módszerek alkalmazásának. A bizonytalan adatok segítségével kapott hozzávetôleges eredmény még mindig jobban támogatja a menedzseri döntések meghozatalát, mint a eljes bizonytalanság.

\section{Felhasznált irodalom}

Bellman, R.E. - Zadeh, A.L. (1970): Decision-making in a fuzzy environment; Management Sciences, 17(4), 141164. o.

Frisch, M. - Romhányi, G. (szerk.) (1983): Anyagforgalmi diagramok alkalmazása az anyagfelhasználás és a hulladékhasznosítás racionalizálására. Országos Környezetés Természetvédelmi Hivatal, Budapest

Ho, Y.C. - Cao, X.R. (1991): Perturbation Analysis of Discrete Event Dynamic Systems; Boston: Kluwer Academic Publisher

Hillier, F.S. - Lieberman, G.J. (1995): Introduction to Operations Research; McGrew-Hill, Inc.

Koltai, T. - Tatay, V. (2009): Application of fuzzy parameters in production planning models, MicroCAD 2009 International Scientific Conference (accepted for publication) Koltai, T. - Tatay, V. (2008): A Practical Approach to Sensitivity Analysis of Linear Programming under Degeneracy in Management Decision Making, 15th International Working Seminar on Production Economics, Innsbruck, Austria, Pre-Prints Volume III., 223-234. o.

oltai, T. (2007): Robustness of a Production Schedule to Inventory Cost Calculations; International Journal of Production Economics (accepted for publication, doi: 10.1016/j.ijpe.2006.12.059)

Koltai, T. (2006): Termelésmenedzsment; Budapest: Typotex Kiadó

Koltai, T. - Terlaky, T. (2000): The difference between the managerial and mathematical interpretation of sensitivity results in linear programming; International Journal of Production Economics, 65, 257-274. o.

Koltai, T. - Larraneta, J. - Onieva, L. (1993): Examination of the sensitivity of an operation schedule with perturbation analysis; International Journal of Production Research, 31(12), 2777-2787. o.

VEZETÉSTUDOMÁNY
Kovács Z. (2008): Karbantartási stratégiák Monte-Carlo optimalizálása; Szigma, 39(3-4), 185-198.

Kovács Z. (2001): Termelésmenedzsment.

Interaktív bevezetés a termelórendszerek tervezésébe, szervezésébe, irányításába. Veszprémi Egyetem Kiadó, Veszprém

Kövesi J. - Német, I. - Szabó G. Cs. - Valkai S. (1991): Termelóberendezések megbízhatóság alapú karbantartása. Budapesti Múszaki Egyetem, Mérnöktovábbképzó Intézet, Budapest

Ragsdete, C.T. (2007): Managerial Decision Modeling. Thomson South-Western
Shih, L-S. (1999): Cement transportation planning via fuzzy linear programming, International Journal of Production Economics, 58, 277-287. o.

. Korlátozott racionalitás; Budapest: Kozgazdasagi és Jogi Konnyvkiadó

Koperationa esearch; European Journal of Operational Research, 13(3), 201-216. o.

Egyetem Kiado, Egyetem Kiado, Pécs

Wesley Publishing Company 